\title{
SILVICULTURAL TASKS SCHEDULING OPTIMIZATION: A CASE STUDY OF FUNCTIONS AND METHODS
}

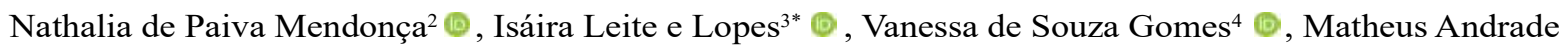

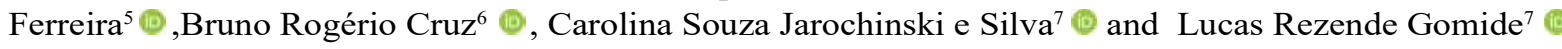

\footnotetext{
${ }^{1}$ Received on 02.02.2021 accepted for publication on 27.10.2021.

${ }^{2}$ Suzano Papel e Celulose, Aracruz, ES - Brasil. E-mail: <nathalia.p.mendonca@hotmail.com>.

${ }^{3}$ Universidade Federal de Lavras, Programa de Pós-Graduação em Engenharia Florestal, Lavras, MG - Brasil. E-mail: <isairaleite2010@ gmail.com>.

${ }^{4}$ Bracell, Alagoinhas, BA - Brasil. E-mail: <vanessadesouzagomes@hotmail.com>.

${ }^{5}$ Remsoft, Vitória, BA - Brasil. E-mail: <matheus.ferreira@remsoft.com>.

${ }^{6}$ Companhia de Ferro Ligas da Bahia, Pojuca, BA - Brasil. E-mail: <brunor.cruz@hotmail.com.br>.

${ }^{7}$ Universidade Federal de Lavras, Departamento de Ciências Florestais, Lavras, MG - Brasil. E-mail: <carolina.jsilva@ufla.br> and $<$ lucasgomide@ufla.br>.

*Corresponding author.
}

\begin{abstract}
Scheduling problems are tasks of the operational routine in companies, which demand an optimal solution to support the decision. However, these problems have not been frequently investigated in forestry science. Therefore, it was proposed to describe a mathematical formulation for silviculture optimization under scheduling restriction of the workforce/sequencing of tasks (SSRCMM). Seeking the most suitable method to solve this combinatorial problem, two strategies were compared: i) Integer Linear Programming (ILP) and ii) simulated annealing (SA). The main criteria to assess strategies' performance were to provide feasible solutions at an acceptable processing time and final project cost. The instance approached is a real problem outlined in 32 stands and five silvicultural tasks scheduled within a 40-day deadline. Three objective functions were also tested, defining case studies $(\mathrm{S})$ to attend to the recurring managers' decisions by minimizing: $\mathrm{S}_{1}$ - project cost, $S_{2}$ - makespan, and $S_{3}$ - workforce usage. The results reveal a robust model to support the forest planner in operational-level tasks. The ILP achieved the optimal solution only for the minimization of the project cost $\left(\mathrm{S}_{1}\right)$ due to the delay in processing time of the other case studies. Thus, the SA stands out as an efficient method to solve the SSRCMM by providing satisfactory solutions in a reduced time. All the objective functions fitted properly with their proposed goals. The makespan and workforce usage functions increased by US\$1,820.29 $\left(\mathrm{S}_{2}\right)$ and US $\$ 2,146.39\left(\mathrm{~S}_{3}\right)$ from the $\mathrm{S}_{1}$, respectively, to finish the project earlier and reduce the oscillation of workforce usage over the days. Facing these findings, it is suggested that future researchers incorporate other challenges in decision-making, involving a multi-objective formulation or methods to reveal new insights for forest management and planning.
\end{abstract}

Keywords: Integer linear programming; Simulated annealing; Operational research.

\section{OTIMIZAÇÃO DO AGENDAMENTO DE ATIVIDADES SILVICULTURAIS: UM ESTUDO DE CASO DE FUNÇ̃̃ES E MÉTODOS}

\begin{abstract}
RESUMO - Problemas de agendamento são tarefas da rotina operacional presentes nas empresas, que exigem uma solução ótima para apoiar a decisão. No entanto, esses problemas ainda não foram investigados com frequência na ciência florestal. Neste sentido, propôs-se descrever uma formulação matemática para a otimização da silvicultura sob restrição de agendamento da mão de obral sequenciamento das atividades (SSRRMM). Buscando o método mais adequado para solucionar este problema combinatório, comparou-se duas estratégias: i) Programação Linear Inteira (PLI) e ii) Simulated annealing (SA). Os principais critérios para avaliar o desempenho das estratégias foram fornecer soluções fáctiveis em tempo de processamento e custo final do projeto aceitáveis. A instância abordada é um problema real contendo 32 talhões e cinco atividades silviculturais programadas dentro de um prazo de 40 dias. Testou-se ainda três funções objetivo, definindo estudos de caso (S) para atender às decisões recorrentes dos gestores, minimizando: $S_{1}$ - custo do
\end{abstract}

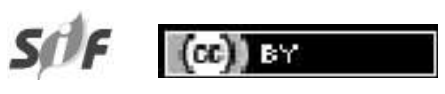

Revista Árvore 2022;46:e4602 http://dx.doi.org/10.1590/1806-908820220000002 


\begin{abstract}
projeto, $S_{2}$ - makespan e $S_{3}$ - utilização da mão de obra. Os resultados revelam um modelo robusto para apoiar o planejador florestal em tarefas a nível operacional. O PLI alcançou a solução ótima apenas para a minimização do custo do projeto $\left(S_{1}\right)$ devido à demora no tempo de processamento dos outros estudos de caso. Desta forma, destaca-se o SA como um método eficiente para solucionar o SSRRMM, fornecendo soluções satisfatórias em um tempo reduzido. Todas as funções objetivo se ajustaram adequadamente aos seus objetivos propostos. As funções de makespan e de uso da mão de obra aumentaram US\$ 1.820,29 ( $\left.S_{2}\right)$ e US\$ 2.146,39 (S3) em relação ao $S_{1}$, respectivamente, para terminar o projeto mais cedo e reduzir a oscilação do uso da mão de obra ao longo dos dias. Diante dessas descobertas, sugere-se aos futuros pesquisadores incorporar outros desafios na tomada de decisão, envolvendo uma formulação multi-objetivo ou métodos para revelar novos insights dentro do manejo e planejamento florestal.
\end{abstract}

Palavras-Chave: Programação linear inteira; Simulated annealing; Pesquisa Operacional.

\section{INTRODUCTION}

The wood supply chain for forest products is usually associated with large-scale areas (Bouchard et al., 2017). D'Amours et al. (2008) emphasize that the forest supply chain comprises a temporal sequence of several forest tasks in the field campaign, which transforms the wood raw material into marketable products. Usually, the results are affected when some unexpected task delays occurred which depends on environmental conditions, forest yield, and management regime. Besides, the silvicultural condition depends on a high set of tasks to be executed combined with the availability of resources (renewable or not), lack of trained manpower, the indefiniteness of silvicultural procedures, difficulties in planning the operations due to the climate conditions, and the maintenance of machines and equipment.

In this sense, the early point of any forest organization is the silviculture planting or regeneration procedure. These practices are crucial for meeting the forest products demands over time. This fact is confirmed when forest companies are investing in clones, equipment, and scientific methods to increase the trees yield and reduce the risks over the decades. An example is observed for Brazilian eucalyptus plantations with short rotation and some of the most productive forest plantations in the world, sustaining mean growth rates of $50 \mathrm{~m}^{3} \mathrm{ha}^{-1}$ year $^{-1}$. The technological advances reflect in the increasing the silvicultural activities (site preparation, spacing, fertilization, control of leaf-cutting ants and weeds, irrigation, pruning, and thinning) and prescription rules to maximize the yield production. On the other hand, the decision-making process became more complex due to a large amount of information and, therefore, the operational research (OR) methods play the role support the supply chain activities by providing models for its optimization (Barbosa-Póvoa et al., 2018).

Kaya et al. (2016) give a full picture of the forest optimization problems for solving by mathematical methods. It is worth noting that forest optimization modeling had a significant publication level last years (Belavenutti et al., 2018). However, most studies involve the optimization of activities related to phases of harvesting and transportation, so there is a gap in the approach to activities that precede these phases, such as forest establishment, inventory, and management (Meneguzzi et al., 2020). Therefore, the question involving planning, scheduling, and sequencing for silvicultural tasks must be explored in the forest context.

The task sequencing problem is usually defined and modeled as a job shop scheduling problem (JSSP). The JSSP is a combinatorial optimization problem and consists of scheduling a set of $n$ jobs on a set of $m$ machines, at specified processing times (Chaudhry and Khan, 2016). The scheduling and sequencing problems are important for operation planning because they can support decisions that involve available forest resources. In this sense, the workforce scheduling and routing problems (WSRPs) are considered to be an actual class of problems that most companies face (Castillo-Salazar et al., 2016). As an example, the study of Hachemi et al. (2013) delineated a problem of scheduling and daily log transportation that were solved sequentially, aiming at minimizing the cost of trucks and unproductive waiting time for loading and

Revista Árvore 2022;46:e4602 
unloading machines. The idea behind truck routing is very close to the silvicultural tasks according to some circumstances where both problems need to define the scheduling overtime.

Today, a current resolution of scheduling problems is considered a challenging task (Hachemi et al., 2011), and most of them are classified as NPhard (Nondeterministic polynomial-time hard). Usually, most of these real problem demands high computational process and time for an optimal solution. Alternately, meta-heuristic methods are strong enough in solving hard and complex problems (Babapour et al., 2018). In the last two decades, the meta-heuristics have been applied in a wide range of forest optimization problems, such as harvest planning (Borges et al., 2014), forest fire risk (GonzálezOlabarria and Pukkala, 2011), thinning schedules (Moriguchi et al., 2017). Despite the integer problem or technique applied the Simulated Annealing (SA) is a robust and trustable method for solving optimization problems (Gallo and Capozzi, 2019). The SA is based on the analogy to thermodynamics, inspired by the process of metals cooling. It is a probabilistic algorithm of local search that demands low consumption of computer memory.

Given the importance of the scheduling problem for operations planning, this research describes the mathematical formulation for silviculture optimization under the workforce scheduling/sequencing tasks constrained. In this sense, we have tested three types of objective functions (project costs, makespan, and workforce usage) and two solving procedures (exact and approximate solution). Complementary, we desire to answer the following research questions: a) what are the impacts of the model formulation on processing times and the total cost of silvicultural tasks? b) what are the benefits of using the model at operational planning? c) Is there any advantage of using Simulated Annealing (SA) as an alternative method?

\section{MATERIAL AND METHODS}

\subsection{Definition of the silvicultural tasks scheduling problem}

The silvicultural problem is described as a technical sequence of tasks and prescriptions scheduled previously for each stand. Therefore, this forest work was ordered, and the management team pointed out when the tasks, costs, sequence, and duration occurred over the days. We have assumed that any task may be done when the team arrived at the stand. For economic reasons, the hour consumption of machinery and workforce usage for each stand and task was performed in the working shift. Thus, the hour service is not constant within stands and may change by stand size, work team efficiency, and the silvicultural task type. Moreover, some of these tasks request a specified time window to happen and/ or dependency from previous tasks. This processing time window is the interval of time available for the task execution and it is previously defined by the task dependencies. Daily, the resources (employees/ machinery) are limited which increases the complexity problem. At the other extreme, we do not take account of the routing problem of the team within stands and tasks. Finally, the silvicultural problem is a real business case that covers 900 ha of Eucalyptus spp. divided into 32 stands established for commercial use. The stands sizes vary between 8 and 48 hectares, and we assume an operational level focus on five silvicultural activities or tasks: $\mathrm{A}_{1}$ - ant combat 1 (systematic control); $\mathrm{A}_{2}$ - ant combat 2 (local control); $\mathrm{A}_{3}$ - mechanized stand soil preparation; $\mathrm{A}_{4}$ - plantation and $\mathrm{A}_{5}$ - post-planting fertilization. However, the set of tasks associated with each stand is heterogeneous and relay on their silvicultural prescription. Thus, the prescription percentage of the tasks are A1 (12.5\%), A2 (34.4\%), A3 (50\%), A4 (75\%), and A5 (100\%) on the total number of stands. The planning horizon was established in 40 days and six hours effective per day (Figure 1).

The temporal dependence connects two sequential tasks and needs to be followed to make sense of the silvicultural activity results. Moreover, we define that the same team is not allowed to start a task $n+1$ until the previous task $n$ is not completed. Thus, the task $A_{2}$ depends on the end of task $A_{1}$ and so on (Figure 1), but the temporal dependence is not similar for all tasks, being zero, three, zero, and one day between activities $A_{1}$ and $A_{2}, A_{2}$ and $A_{3}, A_{3}$ and $\mathrm{A}_{4}, \mathrm{~A}_{4}$ and $\mathrm{A}_{5}$, respectively. In the end, it has been established a group of different teams responsible for the execution of scheduled tasks. The team members were not fixed which means some rearrangement of combination employees and multiple modes of executing the project is possible (Table 1), where the displacement of the teams was not computed at all.

Revista Árvore 2022;46:e4602 


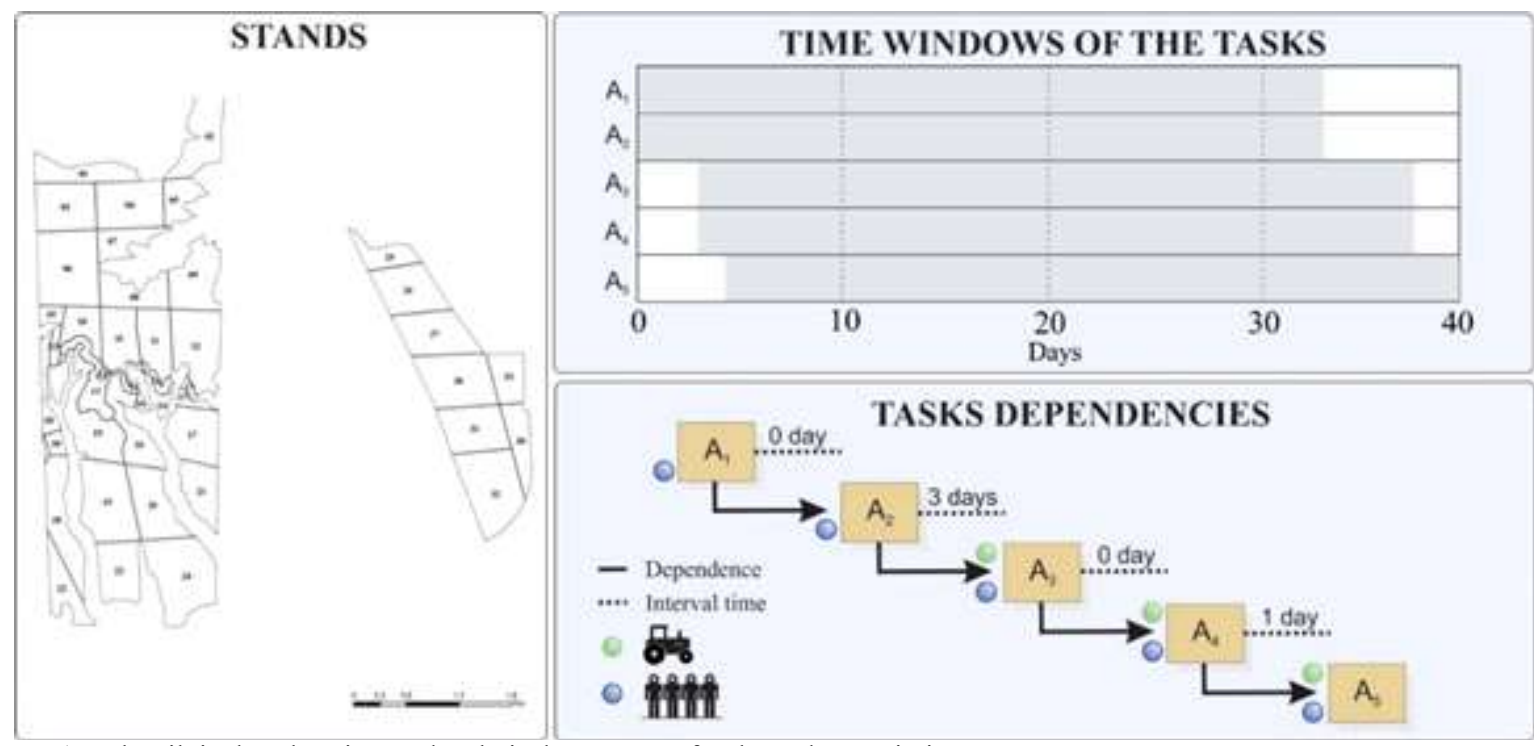

Figure 1 - The silvicultural project and technical sequence of tasks and prescriptions.

Figura 1 - O projeto silvicultural e a sequência técnica das atividades e prescrições.

\subsection{Integer Linear Programming model for solving the silvicultural tasks scheduling problem}

The problem statement is the silvicultural tasks scheduling with resource constraints and multiple execution modes (SSRCMM). We set up the manpower scheduling problem and scheduling with temporal precedence (Bredstrom and Ronnqvist, 2008) applying integer linear programming. The objective functions were written individually to minimize: a) Project cost (Equation 1) - the amount of financial resource spend to reach the silvicultural project goals within the planning horizon, b) Makespan $M$ (Equation
2) - the length of time that elapses from the start of work to the end, and c) workforce usage (Equation 3 ) - the used hours $h$ of manpower over the planning horizon. The decision variable $\mathrm{x}_{\text {sip }}^{\text {at }}$ is binary $\{0,1\}$ to scheduling the task $a$ and designate the team $t$ for the stand $s$. The task duration for team $t$ starts on day $i$ and ends on day $j$ which $i \varepsilon z^{+}: 1 \leq i, j \leq p, i \leq j$ and $j-i=p, p \varepsilon$ $\{s, a, t\}$ are the consumed days. The $I$ index indicates the set of starts day possible to perform some task by some team. Therefore, team performance is related to the task, stand size and efficiency which affect the cost $c$ (US\$). Let $S, A$, and $T$ be a finite set of stands, tasks, and team, respectively.

Table 1 - Description of silvicultural tasks and teams based on resource arrangement, efficiency and cost.

Tabela 1 - Descrição das atividades silviculturais e equipes com base no arranjo dos recursos, eficiência e custo.

\begin{tabular}{|c|c|c|c|c|c|}
\hline \multirow[b]{2}{*}{ Task } & \multicolumn{2}{|c|}{ Arrangement (Unit) } & \multirow[b]{2}{*}{ Machines } & \multirow[b]{2}{*}{ Efficiency $\left(\right.$ ha.h $\left.^{-1}\right)$} & \multirow[b]{2}{*}{ Cost(US\$.ha-1) } \\
\hline & Team & Employees & & & \\
\hline \multirow{3}{*}{$\mathrm{A}_{1}$} & 1 & 13 & 0 & 2.36 & 17.78 \\
\hline & 2 & 15 & 0 & 2.73 & 18.06 \\
\hline & 3 & 18 & 0 & 3.27 & 18.33 \\
\hline \multirow{3}{*}{$\mathrm{A}_{2}$} & 1 & 13 & 0 & 4.73 & 8.89 \\
\hline & 2 & 15 & 0 & 5.45 & 9.17 \\
\hline & 3 & 18 & 0 & 6.54 & 9.44 \\
\hline \multirow[t]{2}{*}{$\mathrm{A}_{3}$} & 1 & 3 & 1 & 1.52 & 22.92 \\
\hline & 2 & 4 & 1 & 2.02 & 28.42 \\
\hline \multirow[t]{2}{*}{$\overline{\mathrm{A}_{4}}$} & 1 & 11 & $\overline{0}$ & 1.43 & 24.72 \\
\hline & 2 & 12 & 0 & 1.56 & 25.00 \\
\hline$\overline{A_{5}}$ & 1 & 19 & 0 & 4.32 & 14.26 \\
\hline
\end{tabular}

Revista Árvore 2022;46:e4602 
Minimize Cost $=\sum_{s}^{S} \sum_{a \in s}^{A} \sum_{t \in a}^{T} \sum_{i \in a}^{I} c_{s i p}^{a t} x_{s i p}^{a t}$

Minimize Makespan $=\mathrm{M}$

Minimize workforce $=\sum_{s}^{S} \sum_{a \in s}^{A} \sum_{t \in a}^{T} \sum_{i \in a}^{I} h_{s i p}^{a t} x_{s i p}^{a t}$

The constraints set below (Equation 4) to (Equation 10) are technical and silvicultural prescriptions for the case studies. Constraint (Equation 4) defines that all task scheduling needs to be done only once for any team. In this context, constraint (Equation 5) guarantees the temporal sequence and dependence of two tasks $a$ and $q$ for the stand. Task $a$ has already been executed before the task $q$ and the interval time is associated with $k+d$ periods. The workforce and machine resources are finite and constrained daily according to the equations (Equation 6) and (Equation 7), respectively. The coefficients $w$ and $g$ are the maximum daily resource limit, $v$ and $h$ indicate the hour requested for machine and workforce. The variable $M$ indicates the last day when the last task was finished (Equation. 8). Finally, the nonnegative and binary constraints are declared (Equation 9) and integer (Equation 10).

$\sum_{i \in a}^{I} \sum_{t \in a}^{T} x_{s i p}^{a t}=1 ;, \forall_{\mathrm{s}} \forall_{a \in s}$

$\mathrm{Eq}-4$

$\sum_{i=n}^{T} x_{s i k}^{a t}=\sum_{t \in n}^{T} x_{s(k+d) j}^{q t} ; \forall_{s}, \forall_{a}, \forall_{i \in a}, a<q, q=a+1, d \in q^{\mathrm{Eq}-5}$

$\sum_{s}^{S} \sum_{a \in s}^{A} \sum_{t \in a}^{T} \mathrm{~h}_{s k}^{a t} x_{s i p}^{a t} \leq w_{k}, \forall_{i}, i \leq k \leq j$,

Eq-6

$\sum_{s}^{S} \sum_{a \in s}^{A} \sum_{t \in a}^{T} v_{s k}^{a t} x_{s i p}^{a t} \leq g_{k}, \forall_{i} i \leq k \leq j$

Eq-7

$M \geq j x_{s i p}^{a t}, \forall_{s}, \forall_{a}, \forall_{t}, \forall_{i \in a}$

$x_{\text {sip }}^{a t} \in\{0,1\}$

$\mathrm{M} \in \mathrm{Z}^{+}$

Eq-10

\subsection{Simulated Annealing algorithm for solving the silvicultural tasks scheduling problem}

The scheduling problem is a difficult problem and complex (NP-hard) to solve with exact algorithms. Given the problem, this optimal solution is sometimes less important when we have a limited time to make the decision plan. Based on this assumption, the stochastic algorithms are usually tested in many optimization problems to evaluate their performances and often find a solution near-optimal. The local search strategy begins with an initial solution $X$ and later randomly generates a new solution $X^{\prime}$. The cooling schedule is used to reduce the probability of accepting a poor solution. Additionally, the stop criteria are met when reaching the final temperature. The metropolis rule figures out the local optimum solution. In this work, the SA parameters were an initial temperature of $10^{6}$, a local random search of $10 \%$; cooler function $T_{i}=$ $0.999 T_{i-1}$; and 50,000 iterations after preliminary tests.

\subsection{Case studies and solution performance}

The silvicultural tasks scheduling problem was converted into three case studies to check the performance of each model functions and constraints. These case studies were inspired by a real forest industry prescription and focus on three operational conditions. The first case or general case $\left(\mathrm{S}_{1}\right)$ is associated with financial trends for finding the minimal cost of all tasks. Here, the objective function has similar thinking of the minimum cost and finish the scheduling. The base of this principle is questionable when economic and environmental risks are present and may delay the process. Therefore, the second objective function $\left(\mathrm{S}_{2}\right)$ was suggested to accelerate the finish of the last task. Usually, the forest sector has been contracting outsourced labor in many activities and sometimes they must speed up the process. In such cases, the makespan is desirable instead of only minimal cost. The last objective function $\left(\mathrm{S}_{3}\right)$ could be applicable when the workforce is insufficient, rare, or requested for many other forest tasks. The meaning of this strategy is not focused only to reduce cost but on the balance between the first e second objective functions for silvicultural tasks scheduling. Thereby, the three study cases size is equal for comparison criteria and we only change the objective functions, except for makespan where we add the constraint (Equation 8).

We process the models following two mathematical strategies, (i) the exact solution with branch-and-bound algorithm and (ii) simulated annealing. The formulation of integer linear programming was run on software LINGO $\AA$ (LINDO Systems Inc., 2016), version 15.0 of academic license. The metaheuristic Simulated Annealing was performed by the software Microsoft ${ }^{\circledR}$ Visual Basic

Revista Árvore 2022;46:e4602 
6.0. It is also important to note that many stochastic optimization methods need a range of solutions and not only one run time process. Usually, the local optimum solution may affect the final solution, and errors could infer its efficiency. Simulated annealing is a robust algorithm to escape from local optimum (Gallo and Capozzi, 2019). However, we decided to run 30 times for every case study independently to remove any bias. The set of final solutions analysis is recommended and important for any local search procedure. Further, the best solution was chosen to compare with the exact method. The last information extracted was (a) total cost, (b) workflow duration; and (c) workforce usage. We illustrate the task scheduling solution by applying the Gantt chart to summarize the details of the model and the decision-making process.

\section{RESULTS}

The exact solution was found only for the first objective function (Table 2). In general, the silvicultural tasks scheduling problem with resource constraints and multiple execution modes (SSRCMM) is hard to solve using exact algorithms. So, it is rational to accept a good solution instead of the optimum for many reasons, such as short deadline time to plan the scheduling. However, the first bound was met for the last two functions and could be used to compare with simulated annealing solutions. Independently of the model, the total of decision variables is 4,722 which combines all tasks scheduling options by a team, day, and stand.

The ILP solution from the objective function S1 is reached faster than the other functions. However, the functions $S_{2}$ and $S_{3}$ demand a long time to meet the first bound, not an optimal solution. Unfortunately, the runtime for ILP problems is not predictable and sometimes the only strategy is using a meta-heuristic algorithm. In this sense, the SA tested to provide good solutions in around half a minute. This algorithm was efficient enough to reduce drastically the runtime, except for $\mathrm{S}_{1}$. Generally, the ILP request more time to present the optimal solution. According to the results, the makespan $\left(\mathrm{S}_{2}\right)$ and workforce usage $\left(\mathrm{S}_{3}\right)$ are more complex than the project cost function $\left(\mathrm{S}_{1}\right)$. We identify the same tendency for SA solutions when measuring the deviation from ILP solutions. As an example, the solutions of $\mathrm{S}_{1}$ for each method are equal and range from $2.52 \%\left(\mathrm{~S}_{2}\right)$ to $7.14 \%\left(\mathrm{~S}_{3}\right)$.

The results of each case study explore a detailed plan which are fundamental points for the silvicultural project. A comparative study of each objective function assesses the better choice for the decision-making process. In this sense, the tradeoff between financial resources and end early the project is pointed out of the model solutions. Whether the choice is a minimal cost, the first objective guarantees this goal reducing US\$1,820.29 $\left(\mathrm{S}_{2}\right)$ and US\$2,146.39 $\left(\mathrm{S}_{3}\right)$ from the final value (ILP). However, the strategy will spend the total period (40 days). We believe of using objective function $\left(\mathrm{S}_{1}\right)$ the lower cost found is associated with low efficiency of the team designated to each task. The makespan function selected only high efficiency and expensive teams to finish the project early (28 days). Therefore, the increased cost of $4.16 \%$ could be attractive for the operational manager. On the other side, the demand for the workforce was also higher in the period, $10 \%\left(\mathrm{~S}_{1}\right)$, and $36.25 \%\left(\mathrm{~S}_{3}\right)$. In contrast, the workforce usage minimization $\left(\mathrm{S}_{3}\right)$ keeps a minimum level of resource daily and less demand for

Table 2 - Integer linear programming and simulated annealing solutions for the silvicultural tasks scheduling problem. Tabela 2 - Soluções de programação linear inteira e simulated annealing para o problema de sequenciamento de atividades silviculturais.

\begin{tabular}{|c|c|c|c|c|c|c|c|c|c|}
\hline \multirow[t]{2}{*}{$\overline{\mathrm{F}}$} & \multirow[t]{2}{*}{ Methods } & \multirow[t]{2}{*}{ Time (s) } & \multirow[t]{2}{*}{ Gap (\%) } & \multirow[t]{2}{*}{ Total cost (US\$) } & \multirow[t]{2}{*}{ Flowtime(days) } & \multicolumn{2}{|c|}{ Resource usage (h) } & \multicolumn{2}{|c|}{ Manpower limits (h) } \\
\hline & & & & & & MP & MAC & Maximum & Minimum \\
\hline \multirow{2}{*}{1} & ILP & 2 & -0.00 & $43,664.07$ & 40 & 11,242 & 290 & 432 & 60 \\
\hline & SA & 35 & & $43,664.07$ & 40 & 11,286 & 290 & 474 & 11 \\
\hline \multirow{2}{*}{2} & ILP $^{*}$ & 86,342 & -7.14 & $45,484.36$ & 28 & 11,009 & 241 & 480 & 0 \\
\hline & SA & 33 & & $44,594.04$ & 30 & 11,286 & 268 & 464 & 159 \\
\hline \multirow[b]{2}{*}{3} & ILP $^{*}$ & 107,775 & -2.52 & $45,810.46$ & 40 & 11,009 & 231 & 306 & 187 \\
\hline & SA & 16 & & $44,880.71$ & 40 & 11,286 & 257 & 354 & 180 \\
\hline
\end{tabular}

F: objective function $\{1$ - project cost, 2 - makespan, and 3 - workforce usage $\}$, ILP: integer linear programming, SA: simulated annealing, MP: manpower, MAC: machine, Manpower limits: balance of maximum/minimum values of manpower hours used over the 40 days, "first bound solution found not the optimum solution and ** optimality gap.

F: função objetivo $\{1$ - custo do projeto, 2 - makespan, and 3 -uso da mão de obra\}, PLI: programação linear inteira, SA: simulated annealing, MP: mão de obra, MAC: máquina, Amplitude da mão de obra: valores máximos/mínimos das horas de mão de obra utilizadas ao longo de 40 dias, "a primeira solução fáctivel não encontrou a solução ótima e ${ }^{* *}$ gap de otimalidade.

Revista Árvore 2022;46:e4602 
this resource than $\mathrm{S}_{1}(25.54 \%)$ and $\mathrm{S} 2(4.32 \%)$. The other advantage is an even flow of workforce usage over time. The final cost also is only $0.7 \%$ higher than the makespan function (Figure 2).

The silvicultural tasks schedule generated for objective function $\mathrm{S}_{2}$ through the $\mathrm{SA}$ algorithm is displayed in the Gantt chart (Figure 3). For instance, it is possible to track the tasks in time over the period and their execution within stands. This temporal and spatial information offers a positive contribution for companies to integrate a control program reference with resources daily. Besides, the case studies
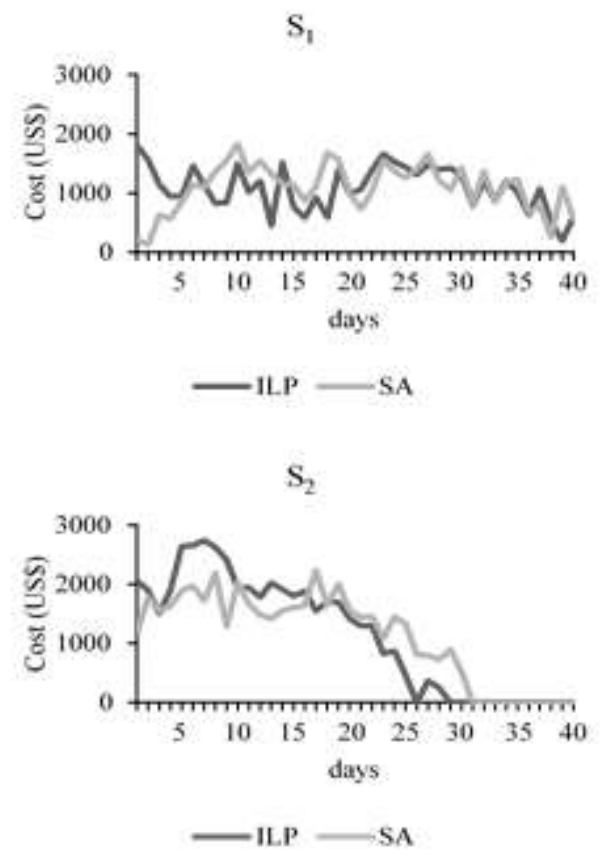

$\mathrm{S}_{3}$

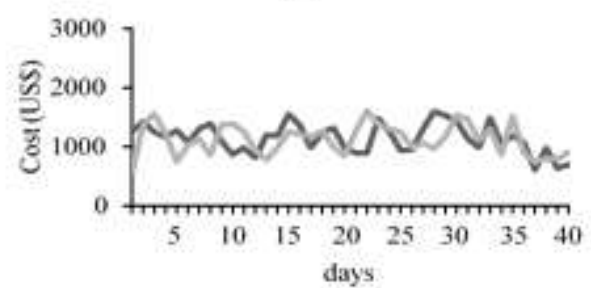

$\longrightarrow$ ILP $\longrightarrow$ SA presented a range of stands with multiple/single tasks scheduled following the silvicultural prescription. The Gantt chart is still an important tool in project and program management as a rich output. These results are systematically checked considering the PDCA process (plan-do-check-act) for continuous improvement of the project planning (Nsafon et al., 2020).

\section{DISCUSSION}

Today, forest planning is supported by optimization technics to minimize the risk and
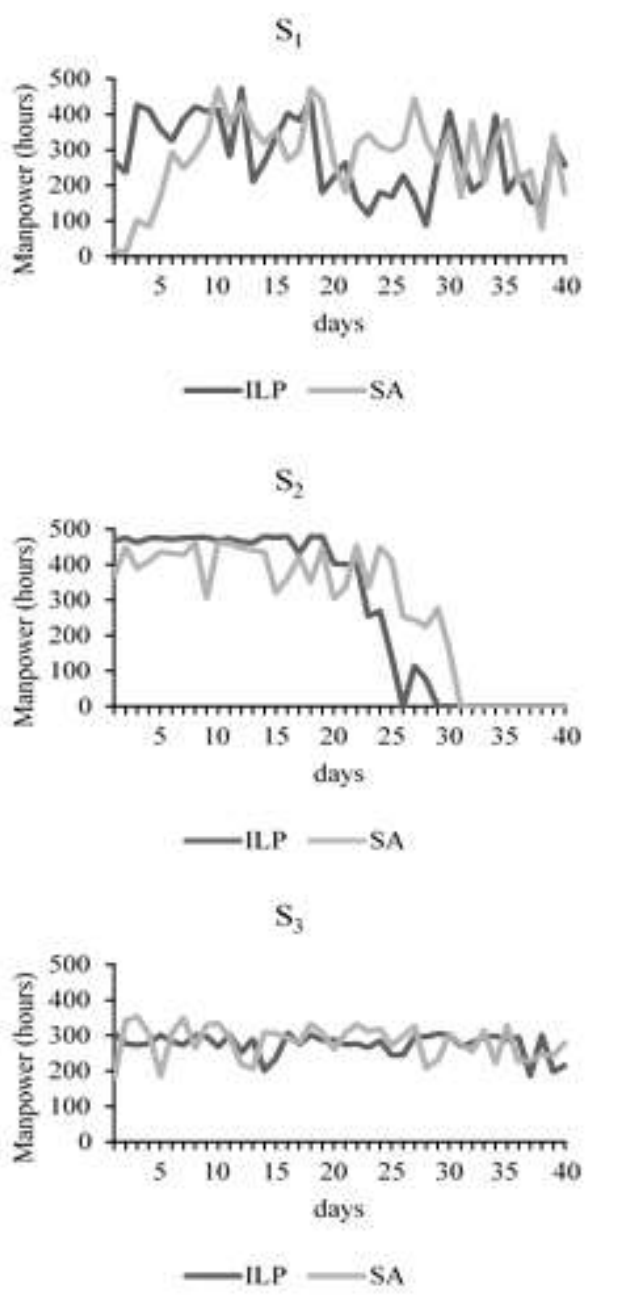

Figure 2 - Daily of silvicultural tasks and resources prediction from integer linear programming and simulated annealing algorithm solutions.

Figura 2 - Predição diária dos recursos e atividades silviculturais a partir de soluções da programação linear inteira e do algoritmo Simulated annealing.

Revista Árvore 2022;46:e4602 


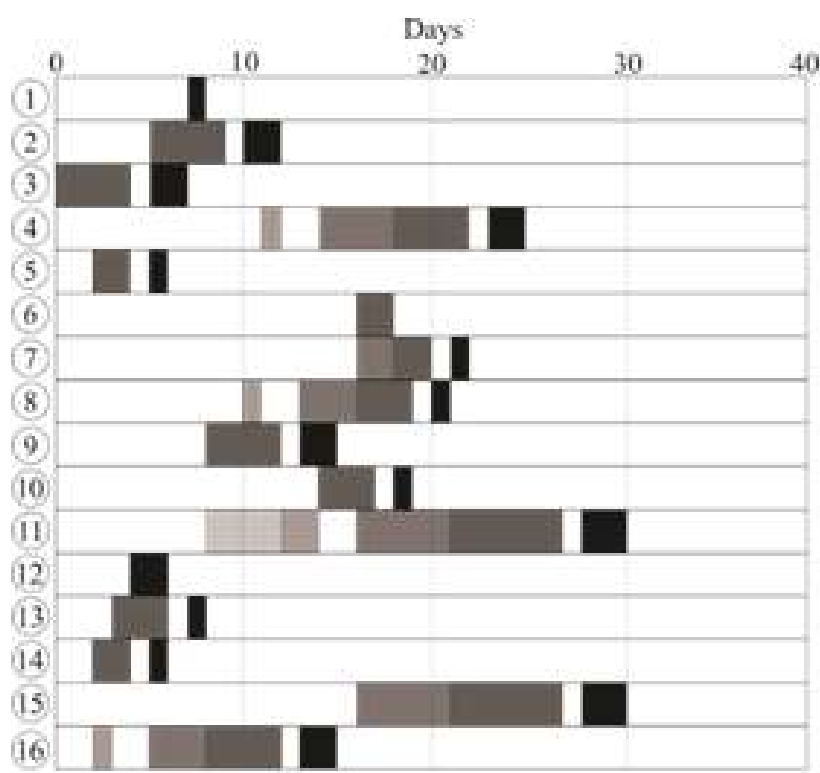

Figure 3 - Daily silvicultural tasks scheduled from objective function $\mathrm{S}_{2}$ using the SA method.

Figura 3 - Tarefas silviculturais diárias programadas a partir da função objetivo $S_{2}$ usando o método $S A$.

increase the success of the industry (Belavenutti et al., 2018). In this scope, the forest services are usually wide of details, demands, and task sequences that request specialized work. The models we have shown has great potential for helping some branch of wood supply chain, perhaps if we have defined the task team route, they should be more realistic. The study cases achieve the main purpose and the SSRCMM was solved by the proposed methods, highlighting the potential of SA. Metaheuristics are a powerful technique that enables to hand dynamic tasks, reducing the processing time (Augustynczik et al., 2016) and with high solution quality. In terms of computational time, SA provided improvements for most of the case studies evaluated. The difference in time resolution among methods is significant where SA reduced $95.7 \%$ on average, except for $\mathrm{S}_{1}$. Moreover, in all the case studies, we identify the SA success by the deviation value of the exact solution between zero to $7.14 \%$. The results corroborate the Borges et al. (2014) presented solutions close to the optimum and with reduced processing times.

With the advance of new technologies and systems become easier to obtain models that meet the time demands required to solve complex problems in the industry, once is desirable fast solutions in a few hours or days. In such cases, therefore, time represents a valuable resource for companies mainly at the operational level (Santos et al., 2019). Then definitely, the computation time may be a limiting factor to the applicability of some optimization techniques (François et al., 2017) as observed in two functions $\mathrm{S}_{2}$ and $\mathrm{S}_{3}$. We highlighted the suit of SA for solving the problem. These results corroborate the study by Jin et al. (2016) that recommend the use of SA in forest planning when the solutions must be found quickly.

Generally, the forest tasks are worked under environmental conditions and risks of delay. Daily, the control of the silvicultural task needs to be checked to guarantee minimal deviations. In such cases, usually, new plans must be rewrite and our model is dynamic to accept changes for new planning. Instead of delay, we suggest the makespan for reduction of the time project execution. The objective function (S2) has proven to be an excellent alternative with a low increased cost which results in 28 days to finish the project. Therefore, even though increasing the costs when accelerated the tasks ends, the $\mathrm{S}_{2}$ is still a desired case study due to some situations as a deviation of

Revista Árvore 2022;46:e4602 
goal productivity, financial problem, environmental condition, accidents, and unable machinery working. The makespan uses are also reinforced by François et al. (2017) at the tactical planning level and wood supply for transport capacity task. The author's model was set up to minimize the multiobjective function which includes the makespan subject to some technical and operational constraints. As expected, their results present a time reduction (five to four days) and use $88 \%$ of the available transport capacity. Even these values, the forest industry has not yet been applying this function. Furthermore, the makespan allows decision-makers greater flexibility for finding feasible solutions to the goals.

Manpower is one of the most important variables for decision-makers even for the basic services. However, workforce usage is influenced by service, experience, and task cost (Doumic et al., 2017). Therefore, there are many alternatives to reduce this last attribute and the most common practice is outsourcing for the forest sector (Štěrbová et al., 2019). Our third objective function S3 was designed to reduce the workforce usage and the results were similar to $S_{2}$ but less than $S 1$. In cost-benefit of $S_{2}$ are the low peak and constant workforce usage daily. Indeed, there is substantial evidence of $\mathrm{S}_{3}$ been an option to control this factor and also its oscillation according to the maximum peak values, $29.16 \%$ (S1$\left.\mathrm{S}_{3}\right)$, and $36.25 \%\left(\mathrm{~S}_{2}-\mathrm{S}_{3}\right)$.

The making decision process demands a diversification of ideas to elaboration on the model and constraints, based mainly on the market perspectives, industry capacity, and financial support. Unfortunately, the traditional approach tends to focus only on maximizing profits, which has not been enough for forest planning. The outputs from the SSRCMM model allows for more detailed and flexible planning. Such flexibility is provided by diversifying case studies based on different objective functions. For these reasons, the outputs present as advantages: enable better integration with the other areas of the company and facilitating a re-planning or meeting the conditions of deviations from the goal, in the face of uncontrolled events. Despite these objective function type, an advantage concerning the final decision depends on the global economic moment. The timing of this stage has been constantly changing summing up to new advances in forest operations and tree genetic improvements. Nowadays, new challenges are requested to fill the optimization model gaps which include social and ecological criteria as noted in Serrano-Ramírez et al. (2019), Álvarez-Miranda et al. (2019), and not only economic aspects. On the other side, with a low rate of return on capital the operation of these industries, sooner or later, will damage their economy. However, as their industrial activities expand, this will result in either higher benefits for our society.

\section{CONCLUSIONS}

Our study proposal advanced towards solving scheduling tasks problems, daily often present in forest operational planning. The suggested model may support the silvicultural tasks scheduling with resource constraints and multiple execution modes (SSRCMM). The three tested functions have significant contribution of planning process. Their uses have differences according to the managers' decisions. Conversely, the makespan $\left(\mathrm{S}_{2}\right)$ and workforce usage $\left(\mathrm{S}_{3}\right)$ functions demand higher budgets than the project costs $\left(\mathrm{S}_{1}\right)$ for evidently reasons in our tests. These findings emphasized the relevance of objective function flexibilization to reduce the risk of field working collapses. Due to the problem complexity, we suggest the use of Simulated Annealing (SA) instead of the exact method for further and larger problems. The new insights of the integration between management and planning reveal a promissory frontier of knowledge. Furthermore, our findings encourage future researchers to move forward into new challenges of multi-objective procedures and methods.

\section{AUTHOR CONTRIBUTIONS}

Nathalia de Paiva Mendonça: Conceptualization, Methodology, Mathematical programming, Data analysis, Software, Investigation, Data processing, Statistical analysis, Visualization, Writing and Editing. Isáira Leite e Lopes: Writing-Reviewing and Editing. Vanessa de Souza Gomes: WritingReviewing and Editing. Matheus Andrade Ferreira: Writing-Reviewing and Editing. Bruno Rogério Cruz: Methodology, Mathematical programming, Statistical analysis, and Software. Carolina Souza Jarochinski e Silva: Writing-Reviewing and Editing. Lucas Rezende Gomide: Conceptualization, Methodology,

Revista Árvore 2022;46:e4602 
Mathematical programming, Software, Data analysis, Data processing, Statistical analysis, Visualization, Writing-Reviewing, Editing, Supervision and Project management.

\section{REFERENCES}

Álvarez-Miranda E, Garcia-Gonzalo J, Pais C, Weintraub A. A multicriteria stochastic optimization framework for sustainable forest decision making under uncertainty. Forest Policy and Economics. 2019;103:112-122. doi:10.1016/j.forpol.2018.03.006

Augustynczik ALD, Arce JE, Yousefpour R, da Silva ACL. Promoting harvesting stands connectivity and its economic implications in Brazilian forest plantations applying integer linear programming and simulated annealing. Forest Policy and Economics. 2016;73:120-129. doi: 10.1016/j.forpol.2016.09.007

Babapour R, Naghdi R, Ghajar I, Mortazavi Z. Forest road profile optimization using meta-heuristic techniques. Applied Soft Computing. 2018;64:126137. doi: 10.1016/j.asoc.2017.12.015

Balena F, Fawcette J. Programming Microsoft Visual Basic 6.0. Vol. 1. Microsoft press: Washington; 1999.

Barbosa-Póvoa AP, da Silva C, Carvalho A. Opportunities and challenges in sustainable supply chain: An operations research perspective. European Journal of Operational Research. 2018;268:399-431. doi:10.1016/j.ejor.2017.10.036

Belavenutti P, Romero C, Diaz-Balteiro L. A critical survey of optimization methods in industrial forest plantations management. Scientia Agricola. 2018;75:239-245. doi: 10.1590/1678-992X-20160479

Borges P, Eid T, Bergseng E. Applying simulated annealing using different methods for the neighborhood search in forest planning problems. European Journal of Operational Research. 2014;233:700-710. doi: 10.1016/j.ejor.2013.08.039

Bouchard M, D'Amours S, Rönnqvist M, Azouzi R, Gunn E. Integrated optimization of strategic and tactical planning decisions in forestry. European Journal of Operational Research. 2017;259:11321143. doi: 10.1016/j.ejor.2016.11.022

Bredstrom D, Ronnqvist M. Combined vehicle routing and scheduling with temporal precedence and synchronization constraints. European Journal of Operational Research. 2008;191:19-31. doi:10.1016/j.ejor.2007.07.033

Castillo-Salazar JA, Landa-silva D, Qu R. Workforce scheduling and routing problems : literature survey and computational study. Annals of Operations Research. 2016;239:39-67. doi: 10.1007/ s10479-014-1687-2

Chaudhry IA, Khan AA. A research survey : review of flexible job shop scheduling techniques. International Transactions in Operational Research. 2016;23:551-591.doi: 10.1111/itor. 12199

D’Amours S, Rönnqvist M, Weintraub A. Using Operational Research for Supply Chain Planning in the Forest Products Industry. INFOR: Information Systems and Operational Research. 2008;46:265281. doi: 10.3138/infor.46.4.265

Doumic M, Perthame B, Ribes E, Salort D, Toubiana N. Toward an integrated workforce planning framework using structured equations. European Journal of Operational Research. 2017;262:217-230. doi: 10.1016/j.ejor.2017.03.076

François J, Moad K, Bourrières J-P, Lebel L. A tactical planning model for collaborative timber transport. IFAC-PapersOnLine. 2017;50:1171311718. doi: 10.1016/j.ifacol.2017.08.1695

Gallo C, Capozzi V. A Simulated Annealing Algorithm for Scheduling Problems. Journal of Applied Mathematics and Physics. 2019;7:25792594. doi: 10.4236/jamp.2019.simann

González-Olabarria J-R, Pukkala T. Integrating fire risk considerations in landscapelevel forest planning. Forest Ecology and Management. 2011;261:278-287. doi: 10.1016/j. foreco.2010.10.017

Hachemi N El, Gendreau M, Rousseau L-M. A heuristic to solve the synchronized log-truck scheduling problem. Computers \& Operations Research. 2013;40:666-673. doi: 10.1016/j. cor.2011.02.002

Hachemi N El, Gendreau M, Rousseau L-M. A hybrid constraint programming approach to the log-truck scheduling problem. Annals of Operations

Revista Árvore 2022;46:e4602 
Research. 2011;184:163-178. doi: 10.1007/s10479010-0698-x

Jin X, Pukkala T, Li F. Fine-tuning heuristic methods for combinatorial optimization in forest planning. European Journal of Forest Research. 2016;135:765779. doi: 10.1007/s10342-016-0971-x

Kaya A, Bettinger P, Boston K, Akbulut R, Ucar Z, Siry J, Merry K, Cieszewski C. Optimisation in Forest Management. Current Forestry Reports. 2016;2:1-17. doi: 10.1007/s40725-016-0027-y

LINDO Systems Inc. LINGO. Version 15.0. Chicago, IL: Lindo Systems Inc; 2016.

Meneguzzi CC, Silva GF da, Mauri GR, Mendonça AR, Junior AA de B. Routing model applied to forest inventory vehicles planning. Computers and Electronics in Agriculture. 2020;175:105544. doi: 10.1016/j.compag.2020.105544

Moriguchi K, Ueki T, Saito M. Identification of effective implementations of simulated annealing for optimizing thinning schedules for single forest stands. European Journal of Operational Research. 2017;262:1094-1108. doi: 10.1016/j. ejor.2017.04.037
Nsafon BEK, Butu HM, Owolabi AB, Roh JW, Suh D, Huh J-S. Integrating multi-criteria analysis with PDCA cycle for sustainable energy planning in Africa: Application to hybrid mini-grid system in Cameroon. Sustainable Energy Technologies and Assessments. 2020;37:100628. doi: 10.1016/j. seta. 2020.100628

Santos PAVH dos, Silva ACL da, Arce JE, Augustynczik ALD. A Mathematical Model for the Integrated Optimization of Harvest and Transport Scheduling of Forest Products. Forests. 2019;10:1110. doi: 10.3390/f10121110

Serrano-Ramírez E, Valdez-Lazalde JR, SantosPosadas HMDL, Mora-Gutíerrez RA, ÁngelesPérez G. Optimización de la producción forestal maderable y conservación del ecosistema en bosques comunitarios en el sur de México. Bosque. 2019;40:195-204. doi: 10.4067/S071792002019000200195

Štěrbová M, Stojanovski V, Weiss G, Šálka J. Innovating in a traditional sector : Innovation in forest harvesting in Slovakia and Macedonia. Forest Policy and Economics. 2019;106:101960. doi: $10.1016 /$ j.forpol.2019.101960 